\title{
17. CENOZOIC PALEOTEMPERATURES AT SITE 398, EASTERN NORTH ATLANTIC: DIAGENETIC EFFECTS ON CARBON AND OXYGEN ISOTOPIC SIGNAL
}

\author{
Colette Vergnaud-Grazzini, Laboratoire de Géologie Dynamique, Université Pierre et Marie Curie, \\ 75230 Paris CEDEX 05, France
}

\begin{abstract}
The oxygen and carbon isotopic history at Site 398 , based on analyses of planktonic and benthic foraminifers, is greatly affected by diagenesis and selective dissolution. Nevertheless, a global decrease in surface temperatures of $4^{\circ}$ to $5^{\circ} \mathrm{C}$, and in bottom temperatures of $10^{\circ} \mathrm{C}$ through the Tertiary can be related to the establishment of deep-water circulation from polar origin. At 48 m.y. B.P., a North Atlantic deep-water supply is responsible for increasing primary production and lowering of ${ }^{13} \mathrm{C} /{ }^{12} \mathrm{C}$ ratios. Eocene surface temperatures were about $17^{\circ} \mathrm{C}$. Near the Eocene/Oligocene boundary, an important shift in the oxygen isotope composition of the total calcitic microfaunas is related to the establishment of the psychrosphere, at $\sim 38$ m.y.B.P. Oligocene bottom temperatures were approximately $5^{\circ} \mathrm{C}$ and the surface-to-bottom temperature gradient was near $3^{\circ} \mathrm{C}$.

The onset of major Antarctic glaciations, with Antarctic bottom water and Antarctic Circumpolar Current (ACC) formation, the timing of which is not yet well established, does not provide any striking isotopic change. A first cooling event in the early Miocene ( $\sim 23$ m.y.B.P.) is tentatively referred to the ACC.

Northern latitude Quaternary glaciations are responsible for another important shift in oxygen isotope values. During the Quaternary, bottom water temperatures averaged $4^{\circ} \mathrm{C}$.
\end{abstract}

\section{INTRODUCTION}

Oxygen and carbon isotope ratios were measured on 40 foraminifer samples from DSDP/IPOD Site 398, for the purpose of sketching the paleoenvironmental evolution of eastern North Atlantic waters through Cenozoic time.

\section{The Isotopic Signal}

The comparison between benthic and planktonic species of foraminifers provides useful information on the thermic and haline conditions of the water masses where they built their tests; but this requires that the isotopic signal is well preserved and that the shell carbonate was not subjected to any epigenetic, diagenetic, or selective dissolution process.

For Hole 398 samples, SEM observations (Létolle, this volume) show that the biogenetic carbonates are highly recrystallized. This recrystallization diminishes, however, as the strata become younger, but still persists up to Core 2.

The effects of diagenesis on the isotope record is not understood well. Dissolution alters the original assemblages by selective removal of thin-walled, highly porous, surface-dwelling variants within the same foraminiferal species. These variants correspond to isotopically lighter shells; consequently, the average isotopic composition of the resulting assemblage no longer re- flects the original oxygen isotopic composition: the apparent isotopic temperature could be changed by several degrees Celsius (Douglas and Savin, 1973; Berger and Killingley, 1977).

Fragmented or incomplete shells may be the only material available with old assemblages, as those of Tertiary or pre-Tertiary cores from DSDP holes. The change in the isotopic composition $\left({ }^{18} \mathrm{O} /{ }^{16} \mathrm{O}\right.$ as well as ${ }^{13} \mathrm{C} /{ }^{12} \mathrm{C}$ ratios) when only parts of a shell have been removed by dissolution, is species dependent, and the magnitudes of this change cannot be predicted for fossil species (M. C. Bonneau et al., in preparation). Moreover, if the material contains fragmented tests plus thick-walled resistant variants of the same species, the probability for retracting the original isotopic signal is still less.

Recrystallization also alters the original isotopic composition of a shell. The resulting isotopic signal may reflect the conditions ( $\delta$ water and temperature) in which diagenesis occurred. The more common example is that of calcitic faunas from continental outcrops (pelecypods as well as foraminifers). Recrystallization tends to lower the original isotopic composition since re-equilibration occurred in waters of meteoric or continental origins. In sediments cored at great depth, diagenetic processes may occur through burial and at a temperature depending on the geothermal gradient. For example, assuming a thermal gradient of $3^{\circ} \mathrm{C}$ per 
100 meters, sediments buried at 700 meters (cf. the Eocene cores in Hole 398) are at a temperature near $23^{\circ} \mathrm{C}$ (the sea floor temperature is close to $2{ }^{\circ} \mathrm{C}$ near Site 398). The isotopic composition of calcite which recrystallizes at this temperature, in a water with isotopic composition $=0$ (late recrystallization), should be $-1.4 \%$. Reciprocally, calcite with a $\delta=-1 \%$ recrystallized in water of $-1.2 \%$ (early recrystallization) implies temperatures near $16^{\circ} \mathrm{C}$ with a sea floor temperature of $6^{\circ} \mathrm{C}$ (Oligocene values), the deduced geothermal gradient should be equal to $10^{\circ} \mathrm{C}$, corresponding to about 300 meters burial depth in the sediment (Miocene time). Thus, when looking at the evolution of the isotopic signal registered by benthic and planktonic foraminifers since the Paleocene, one should consider the possible effects of diagenetic processes. These processes may act on the isotopic signal in the same manner as the general climatic evolution.

\section{MATERIAL AND METHODS}

Samples consisting of 15 individuals of planktonic foraminifers or 10 individuals of benthic foraminifers (equivalent to $0.5 \mathrm{mg}$ of carbonate) were analyzed. Organic matter was removed by a 48 -hour clorox treatment; adhering fine-grained matter was removed by ultrasonic cleaning. Carbon dioxide release and calibration procedure were identical to those described by Shackleton and Opdyke (1973). Isotope analyses were performed in a VG micromass-602 C mass spectrometer and calibrated by analyses of standard carbonate samples under identical conditions. Analytical results, referred to the PDB standard, are reported in Tables 1 and 2 and displayed in Figure 1.

Most of the analyses were performed on mixed species assemblages. The isotopic temperature of a sample composed of many individuals of several species is a weighted average of the temperatures at which all the constituents of the assemblage secreted their tests. Thus, paleotemperatures derived from ${ }^{18} \mathrm{O} /{ }^{16} \mathrm{O}$ ratios of mixed species assemblages of planktonic foraminifers should be lower than actual surface temperatures because of the depth distribution of growth habitats. However, the low value of the surface-to-bottom temperature gradient in the Paleogene suggests much smaller differences between surface temperatures and the isotopic temperatures of mixed planktonic assemblages at that time. According to Douglas and Savin (1973), the estimated isotopic temperatures of assemblages of mixed species of planktonic foraminifers are probably within a few degrees of actual surface values in the pre-Neogene and within $6^{\circ} \mathrm{C}$ for the late Neogene. These authors also indicate that the isotopic temperatures of mixed species assemblages of benthic foraminifers also approximate growth temperatures.

\section{PALEOTEMPERATURES EVOLUTION}

We propose the distinction of three "isotopic units" within the Tertiary sequence of Site 398.
TABLE 1

Oxygen and Carbon Isotope Ratios ${ }^{\mathrm{a}}$ for Planktonic Foraminifers at DSDP Site 398

\begin{tabular}{|c|c|c|c|c|c|}
\hline $\begin{array}{c}\text { Ages } \\
\text { (Zones) }\end{array}$ & $\begin{array}{c}\text { Sample } \\
\text { (Interval in } \mathrm{cm} \text { ) }\end{array}$ & Species & ${ }_{8}^{18} \mathrm{O}$ & ${ }^{13} \mathrm{C}$ & $\begin{array}{l}\text { X Dissolution } \\
+ \text { Diagenesis }\end{array}$ \\
\hline \multicolumn{6}{|l|}{ Hole 398} \\
\hline NN 20 & $2-3,84$ & Orbulina & +1.64 & $\begin{array}{l}+1.16 \\
+0.27\end{array}$ & \\
\hline NN 19 & $\begin{array}{l}3-5,20 \\
4-3,125\end{array}$ & Orbulina & +1.12 & +0.85 & \\
\hline \multicolumn{6}{|l|}{ Hole 398B } \\
\hline $\mathrm{NN} 12$ & $1-3,51$ & Orbulina & +0.54 & +0.75 & \\
\hline \multicolumn{6}{|l|}{ Hole 398D } \\
\hline & $1-6,96$ & Orbulina & +0.65 & +1.86 & \\
\hline & $2-2,65$ & Orbulina & +1.11 & +1.46 & \\
\hline N 19.20 & $2-4,20$ & Orbulina & +1.29 & +1.10 & \\
\hline \multirow[t]{7}{*}{ NN 10} & $4-6,141$ & Orbulina & +0.13 & +1.12 & \\
\hline & & Globorotalia & +0.33 & +1.10 & \\
\hline & & Globoquadring & +0.16 & +1.14 & \\
\hline & $5-2,24$ & Mixed species & +1.34 & $+1,48$ & \\
\hline & $5 \cdot 2,124$ & Globoquadrina & +1.18 & +0.86 & \\
\hline & $6 \cdot 5.69$ & Mixed species & +1.17 & +1.39 & \\
\hline & 7.2 .74 & Mixed species & +1.46 & + & $\mathrm{x}$ \\
\hline \multirow[t]{3}{*}{ N 6-N 8} & $8-1,123$ & Mixed species & +1.85 & +1.13 & \\
\hline & $8 \cdot 3,76$ & Mixed species & +0.43 & +1.11 & $\mathrm{x}$ \\
\hline & $9.1,25$ & Mixed species & +1.42 & +1.39 & \\
\hline \multirow[t]{2}{*}{ NN 1.2} & $12-1,106$ & Mixed species & +1.53 & +0.96 & \\
\hline & 12.3 .94 & Mixed species & +1.62 & +1.07 & \\
\hline \multirow[t]{2}{*}{$\mathrm{NP} 24 / 25$} & $13-6,30$ & Mixed species & +0.12 & +0.20 & $\mathrm{xx}$ \\
\hline & & Mixed species & $\begin{array}{l}+0.26 \\
+1.84\end{array}$ & $\begin{array}{l}+0.29 \\
+1.23\end{array}$ & \\
\hline $\mathrm{N}_{2}$ & $\begin{array}{l}15 \cdot 2,11 \\
15 \cdot 3,13\end{array}$ & $\begin{array}{l}\text { Mixed species } \\
\text { Mixed species }\end{array}$ & $\begin{array}{l}+1.84 \\
+1.80\end{array}$ & $\begin{array}{l}+1.23 \\
+0.64\end{array}$ & \\
\hline \multirow[t]{3}{*}{$\mathrm{NP} 22 / 21$} & $20-3,135$ & Mixed species & +0.71 & +1.95 & $x+$ \\
\hline & $22 \cdot 2,120$ & Mixed species & -0.39 & +1.68 & \\
\hline & $23-3,113$ & Mixed species & -1.18 & +1.24 & \\
\hline \multirow[t]{3}{*}{ NP 16} & $24-1,111$ & Mixed species & -0.59 & +1.31 & \\
\hline & $26-1,64$ & Mixed species & -0.77 & $+1,33$ & \\
\hline & $28-5,102$ & Mixed species & -0.64 & +1.15 & \\
\hline \multirow[t]{3}{*}{ NP $13-14$} & $29-5,140$ & Mixed spècies & -0.40 & +0.83 & + \\
\hline & $30-4,54$ & Mixed species & -0.14 & +0.69 & $x+$ \\
\hline & $31-1,33$ & Mixed species & -0.42 & +0.26 & $\mathrm{x}$ \\
\hline \multirow[t]{3}{*}{$\mathrm{NP} 12$} & $32-3,121$ & Mixed species & +0.27 & +1.11 & \\
\hline & $33-5,20$ & Mixed species & +0.49 & +1.06 & \\
\hline & $34-6,95$ & Mixed species & +0.09 & +1.38 & \\
\hline NP 9 & $35-2,16$ & Mixed species & -0.12 & +1.29 & \\
\hline NP 7 & $37-3,113$ & Mixed species & -0.39 & +2.24 & + \\
\hline NP 3 & $39-3,131$ & Mixed species & -0.36 & +1.61 & + \\
\hline \multirow[t]{2}{*}{ NP 1.2} & $40-3,84$ & Mixed species & +0.83 & +1.43 & $\mathrm{x}$ \\
\hline & $41-1.7$ & Mixed species & +0.57 & +0.78 & + \\
\hline
\end{tabular}

${ }^{\mathrm{a}}$ Expressed as deviations per mil from PDB standard,

1) A first unit, corresponding to Paleocene and Eocene sediments up to Core 20, with strong diagenetic effects, coincides with lithologic Units $3 \mathrm{~A}$ and 2.

2) A second unit, corresponding to the OligoceneMiocene sediments, coincides with lithologic Units 1C and $1 \mathrm{~B}$. Dissolution and diagenesis altered the isotopic signal, but the general climatic trends are easily recognizable.

3) A third unit corresponds to lithologic Unit 1A, where the original isotopic signal is much less affected.

\section{First Unit: Paleocene and Eocene Record}

Oxygen isotopic values registered by Paleocene planktonic foraminifers correspond to temperatures between $10^{\circ}$ and $14^{\circ} \mathrm{C}$, assuming that the isotopic composition of the sea water was $-1.2 \%$ (according to Shackleton and Kennett, 1975).

During Eocene time, a general lowering of isotopic values begins approximately in Zone P.7 and ends with Zone P.16. Though the isotopic signal might have been controlled by diagenetic and/or dissolution processes, as inferred by the similarity of benthic and planktonic $\delta^{18} \mathrm{O}$ values through that period, the maximal temperatures that one may calculate are around $17^{\circ} \mathrm{C}$. These values are in good agreement with those calculated for Pacific Sites 277 (Shackleton and Kennett, 1975) or 171 
TABLE 2

Oxygen and Carbon Isotope Ratios ${ }^{\mathrm{a}}$ for Benthic Foraminifers at DSDP Site 398

\begin{tabular}{|c|c|c|c|c|c|}
\hline $\begin{array}{c}\text { Ages } \\
\text { (Zones) }\end{array}$ & $\begin{array}{c}\text { Sample } \\
\text { (Interval in } \mathrm{cm} \text { ) }\end{array}$ & Species & ${ }_{8}^{18} \mathrm{O}$ & ${ }^{13} \mathrm{C}$ & Dissolutior \\
\hline \multicolumn{6}{|l|}{ Hole 398} \\
\hline \multirow[t]{2}{*}{ NN 20} & $2-3,84$ & Melonis & +3.17 & - & \\
\hline & $3-5,20$ & Uvigerina & +4.24 & -1.16 & \\
\hline NN 19 & $4,3,125$ & Pyrgo + Melonis & +2.89 & +0.14 & \\
\hline \multicolumn{6}{|l|}{ Hole 398D } \\
\hline & $1-6.96$ & Gyroidina & +1.93 & - & \\
\hline N.19-20 & $2-4,20$ & Melonis + Uvigerina & +1.64 & & \\
\hline \multirow[t]{3}{*}{ N. $12-13$} & $5-2,124$ & Mixed species & +1.57 & -0.70 & \\
\hline & $5-2,24$ & Mixed species & +2.04 & +0.62 & \\
\hline & $6.5,69$ & Mixed species & +1.30 & +0.02 & \\
\hline \multirow[t]{4}{*}{ N.6-N 8} & $8-1,123$ & Mixed species & $\begin{array}{r}+1.80 \\
+1.80\end{array}$ & $\begin{array}{r}0.58 \\
+0.58\end{array}$ & \\
\hline & $8 \cdot 3,76$ & Mixed species & +0.86 & -0.09 & $\mathrm{x}$ \\
\hline & $9-1,25$ & Mixed species & +2.31 & +0.03 & \\
\hline & $12-3,94$ & Mixed species & +2.14 & +0.31 & \\
\hline \multirow[t]{14}{*}{ N.2 } & $15 \cdot 2,11$ & Mixed species & +1.43 & -0.27 & \\
\hline & $15-3,13$ & Mixed species & +1.80 & +0.64 & \\
\hline & $20-3,135$ & Mixed species & +1.38 & & \\
\hline & $17-3.23$ & Mixed species & +1.65 & -0.71 & \\
\hline & $19.4,79$ & Mixed species & +1.72 & +0.34 & \\
\hline & $22-2,120$ & Mixed species & -1.14 & - & \\
\hline & $23-3,113$ & Mixed species & -0.93 & -0.07 & $\mathrm{x}$ \\
\hline & $24-1,111$ & Mixed species & -1.12 & +0.05 & \\
\hline & $26-1,64$ & Mixed species & -1.20 & -0.73 & \\
\hline & $27-4,117$ & Mixed species & +0.03 & +0.84 & \\
\hline & $28-5,102$ & Mixed species & -0.43 & -0.39 & \\
\hline & $29-5,140$ & Mixed species & -0.33 & - & \\
\hline & $31-1,33$ & Mixed species & -1.58 & - & \\
\hline & $32-3,121$ & Mixed species & -0.52 & -0.23 & \\
\hline
\end{tabular}

${ }^{\mathrm{a}}$ Expressed as deviations per mil from PDB standard.

(Douglas and Savin, 1973). In late Eocene a strong increase is observed in $\delta^{18} \mathrm{O}$ for planktonic $(>2 \%)$ as well as for benthic species $(2.5 \%)$.

\section{Discussion}

Paleotemperatures evaluations can lead to plausible values for surface water temperatures in the Eocene. But the values obtained for benthic assemblages, which are nearly the same as surface values, could hardly be interpreted as evidence for a zero surface-to-bottom temperature gradient. They might signify that one assemblage (planktonic, benthic, or both) may not represent the original isotopic signal. Selective removal by dissolution should lead to higher isotopic values in the more sensitive assemblages, i.e., the planktonic one. This should signify that the benthic forms partially preserved their original isotopic composition, and the planktonic ones were presently more negative than they were originally. But it is difficult to assume an Eocene bottom paleotemperature around $17^{\circ} \mathrm{C}$.

Conversely, if one assumes that epigenetic and diagenetic processes (after burial) and recrystallization changed the original values, as mentioned above, a temperature near $23^{\circ} \mathrm{C}$ and a water around the SMOW should lead to isotopic values very similar to the ones measured $(-1.4 \%)$. This could explain the similarity of planktonic and benthic values. But, we do not really know the time and the actual isotopic composition at which such recrystallizations may have occurred. Nevertheless, this demonstrates that dissolution and diagenetic phenomena may act on the isotopic signal in a way that is not always detectable. We are puzzled by the apparent synchronism of the thermic evolution that appears here, compared with that of the $\mathrm{Pa}$ cific for example. Similar warmings are reported in the late Paleocene, early Eocene, and middle Eocene in South Pacific DSDP Sites 277 and 279A (Shackleton and Kennett, 1975) and in late Paleocene and middle Eocene in the central North Pacific at Site 171. These warming tendencies, occurring in such distal oceans at a time when latitudinal effects did not exist, may have corresponded to a mondial climatic evolution.

The general trends which are reported here for $\mathrm{Pa}$ leocene and Eocene time are in good agreement with the ones deduced from bulk carbonate analyses: warming trends with a maximal effect in Cores 37, 31, and 23. Assuming the bulk carbonates to represent essentially coccolithes (in weight), it is not surprising to find a climatic evolution similar to that of planktonic foraminifers.

\section{$C^{13}$ Data}

Although the isotopic composition of carbon depends on more factors (i.e., isotopic composition of the dissolved bicarbonate, "vital" effect, dissolution processes, and a small temperature effect) one may assume that it depends essentially on the isotopic composition of dissolved bicarbonates.

A general lowering in the isotopic composition, $\max$ imal in Cores 31 through 29 could be correlated with increasing productivity. It corresponds also to a strong decrease of the ${ }^{13} \mathrm{C} /{ }^{12} \mathrm{C}$ ratios of the bulk carbonates in Core 31. This decrease, which dates from 47 to 49 m.y.B.P., may be related to an increase in surface productivity resulting itself from the influx of cold waters which supplied large amounts of nutrients to the euphotic zones. Sedimentological studies (Auffret and Pastouret, in preparation) also indicate increasing surface water productivity from the late Paleocene to middle Eocene in the northeast Atlantic. This coincides approximately with the Pyrenean Orogeny.

In the late Eocene, a rapid evolution towards higher oxygen isotopic compositions is noticeable in both planktonic and benthic assemblages. Maximal $\delta^{18} \mathrm{O}$ values are recorded throughout the Oligocene. In the Pacific Ocean this variation was also detected but do not exceed $1.2 \%$ (Shackleton and Kennett, 1975). The change recorded in bulk carbonates does not exceed $1.5 \%$. The higher shift observed in foraminiferal assemblages in Hole 398 might be the result of diagenetic dissolution processes superimposed on a real climatic change. This shift, which occurred approximately 38 m.y.B.P. coincides with the establishment of the psychrosphere (Berggren, 1977; Kennett and Shackleton, 1976).

\section{Second Unit: Oligo-Miocene Sediments}

Bottom temperatures evaluated from benthic assemblages range between $5^{\circ}$ and $6^{\circ} \mathrm{C}$ in the Oligocene. Plankton samples for the late Oligocene indicate that surface temperatures were identical to bottom temperatures. Possibly, dissolution and diagenesis occurred at the water-sediment interface, increasing the initial isotopic composition of the planktonic foraminifers.

In Core 13, repeated analyses lead to the same low isotopic value. The sample showed poor preservation 


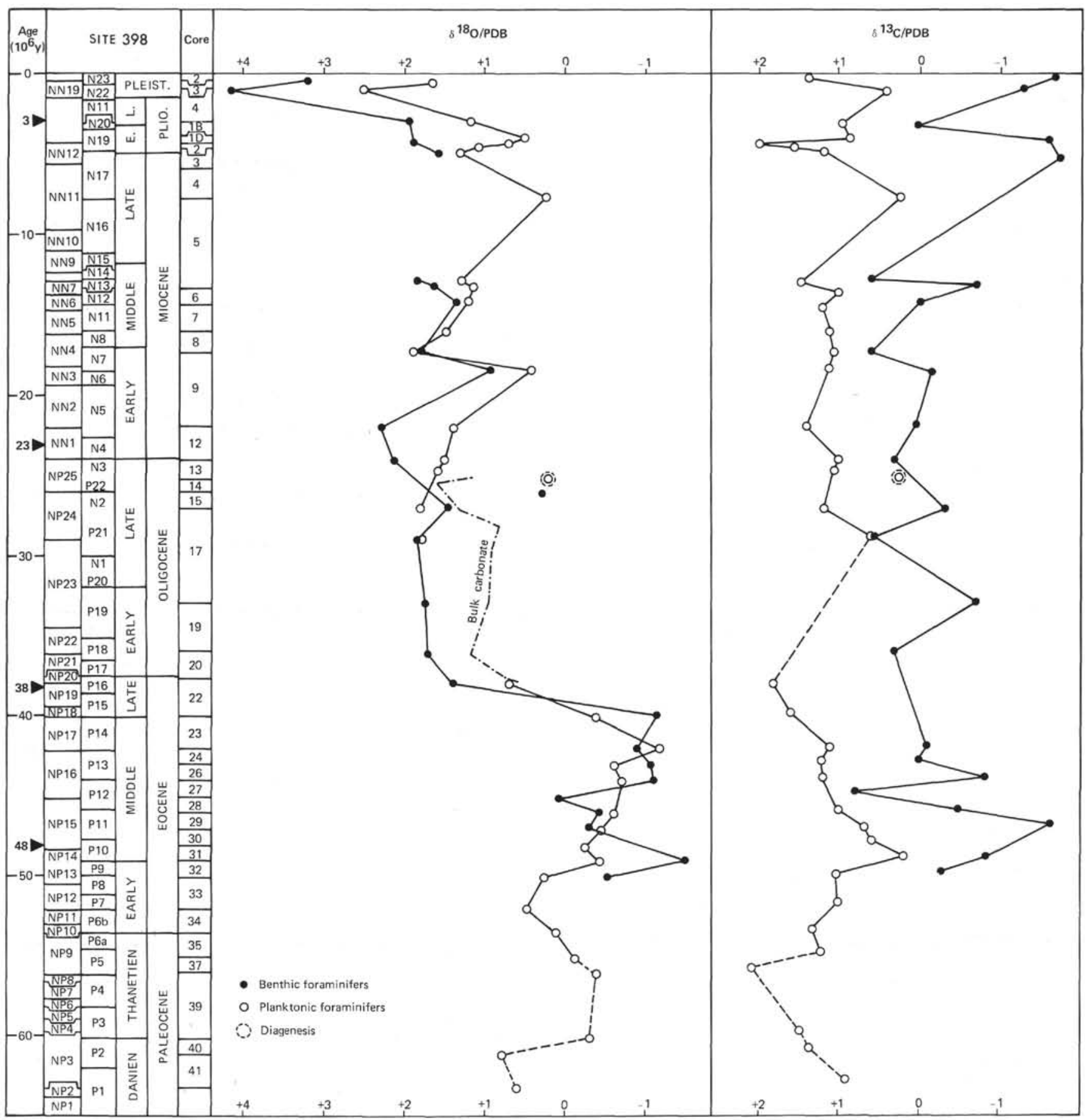

Figure 1. Oxygen and carbon isotopic values for planktonic and benthic foraminifers at DSDP Site 398.

and the results may be meaningless for defining the general evolution of water temperatures.

Oxygen isotopic compositions measured on bulk carbonates for the Oligocene produce averages lower than those for planktonic foraminifers. This should emphasize the probability of a selective dissolution effect on planktonic foraminifers, these being more sensitive to dissolution than coccoliths (McIntyre and McIntyre, 1971; Scheidermann, 1973). The isotopic difference between benthic assemblages and bulk carbonates (i.e., about $0.8 \%$ ) may be the result of a surface-to-bottom temperature gradient of about $3.5^{\circ} \mathrm{C}$ in the Oligocene.

In the early Miocene, benthic and planktonic curves become separated, indicating better preservations. A bottom temperature lowering could possibly be correlated with the establishment of the ACC (about 23 m.y.B.P.).

This is followed by a warming episode, which was determined from foraminiferal assemblages as well as coccoliths, at about 18 m.y.B.P. This could correlate with the flow of warm Mediterranean waters into the eastern Atlantic (Berggren and Hollister, 1974). 
A second warming episode was detected in surface waters (planktonic foraminifers and bulk carbonates) at the level of Core 4. A lowering in the $\delta^{13} \mathrm{C}$ might indicate an increase in surface productivity.

\section{Third Unit: Pliocene and Pleistocene Sediments}

The $1.2 \%$ oxygen isotopic difference between planktonic and benthic carbonates leads to a minimal estimation for a surface-to-bottom gradient of $5{ }^{\circ} \mathrm{C}$. The shift towards high positive values in planktonic and benthic assemblages in the Pleistocene corresponds to the onset of the great northern latitude glaciations.

\section{CONCLUSIONS}

Stable isotope analyses on foraminiferal assemblages from Hole 398 show a global increase in oxygen isotopes through the Tertiary epoch, which averages $3 \%$ for benthic assemblages and $2 \%$ for planktonic ones. Assuming a glacial effect of $0.9 \%$ o corresponding to the major advance of the Antarctic ice cap (Shackleton and Kennett, 1975). we may deduce that a global cooling trend is responsible for a $\delta$ increase of about $2.1 \%$ in benthic foraminifers and $1.1 \%$ in planktonic ones. This suggests that:

1) Bottom temperatures cooled by $10^{\circ} \mathrm{C}$ while surface temperatures only decreased by $4.5^{\circ} \mathrm{C}$. Thus, the surface-to-bottom temperature gradient was $5.5^{\circ} \mathrm{C}$ higher in the late Miocene than in Eocene time.

2) Declines in temperatures were rather rapid, occurring essentially at the Eocene/Oligocene boundary and during the Pleistocene. They were separated by eipsodes of relative temperature stability.

3 ) While the isotopic effect of the major eastern Antarctic glaciation in the middle-late Miocene is not well reflected in our results, the climatic event which marked the Eocene/Oligocene transition might have been strong enough to obliterate part of the diagenetic effects on the isotopic signal. This transition from a set of relatively low isotopic compositions (between 0 and $-1 \%$ ) in the Eocene, to a set of relatively high isotopic compositions in the Oligocene, has been considered to represent the onset of Antarctic bottom-water formation (Kennett and Shackleton, 1976).

Actually the timing of the major Antarctic glacial events which determine the deep circulation is not yet well established, but this transition which coincides with the establishment of the psychrosphere at 38 m.y.B.P. appears to be the most important paleoceanographic event to be reflected in the isotopic signal of eastern North Atlantic faunas.

\section{ACKNOWLEDGMENTS}

Funds for this research were provided by CNRS through Grant Number 604 and ATP-IPOD Grant Number 26-86. I gratefully acknowledge S. Iaccarino for providing foraminiferal smples, A. Longinelli for stimulating discussions, R. Létolle for reviewing and improving the original manuscript and $\mathrm{M}$. Dudouyt for laboratory assistance.

\section{REFERENCES}

Auffret, G. and Pastouret, L., in preparation. Upper Cretaceous to Quaternary sedimentary processes in the Bay of Biscay from textural and coarse fraction studies.

Berggren, W. A., 1977. North Atlantic Cenozoic Foraminifera. Development in paleontology and stratigraphy 6. In Swain, F. M. (Ed.), Stratigraphic micropaleontology of Atlantic basin and borderlands, p. 389-409.

Berggren, W. A. and Hollister, C. D., 1974. Paleogeography, paleobiogeography and the history of circulation in the Atlantic Ocean. In Hay, W. W. (Ed.), Studies in paleo-oceanography: Soc. Econ. Paleont. Mineral. Spec. Publ. 20, p. 126-186.

Berger, W. H. and Killingley, L., 1977. Glacial-Holocene transition in deep sea carbonates: selective dissolution and the stable isotope signal, Science, v. 197, p. 563-566.

Bonneau, M. C., Vergnaud-Grazzini, C., and Berger, W. H., in preparation. Morphologic and isotopic alterations related to dissolution processes in some recent Pacific species.

Douglas, R. G. and Savin, S. M., 1973. Oxygen and carbon isotope analyses of Cretaceous and Tertiary Foraminifera from the central North Pacific. In Winterer, E. L., Ewing, J. I., et al., Initial Reports of the Deep Sea Drilling Project, v. 17: Washington (U.S. Government Printing Office), p. 591-605.

Kennett, J. P. and Shackleton, N. J., 1976. Oxygen isotopic evidence for the development of the psychrosphere $38 \mathrm{~m} . \mathrm{y}$. ago, Nature, v. 250, p. 513-515.

McIntyre, A. and McIntyre, R., 1971. Coccolith concentrations and differential solution in oceanic sediments. In Funnel, B. M. and Riedel, W. R. (Eds.), The micropaleontology of oceans: Cambridge (Cambridge Univ. Press), p. 253-261.

Schneidermann, N., 1973. Deposition of coccoliths in the compensation zone of the Atlantic Ocean. In Smith, L. A. and Hardenbol, J. (Eds.), Proceeding of the symposium on calcareous nannofossils: Gulf Coast Section of the Society of Economic Paleontologists and Mineralogists, p. 140-151.

Shackleton, N. J. and Kennett, J. P., 1975. Paleotemperature history of the Cenozoic and the initiation of Antarctic glaciation: oxygen and carbon isotope analyses in DSDP Sites 277, 279 and 281. In Kennett, J. P., Houtz, R. E., et al., Initial Reports of the Deep Sea Drilling Project, v. 24: Washington (U.S. Government Printing Office), p. 743755 .

Shackleton, N. J. and Opdyke N. D., 1973. Oxygen isotope and palaeomagnetic stratigraphy of Equatorial Pacific Cores V28-238: oxygen isotope temperatures on a $10^{5}$ year and $10^{6}$ year scale, Quat. Res., v. 3, p. 39-55. 